\title{
Distinguish L2 Writing Tension from Anxiety
}

\author{
Tsai, Min-Hsiu, ${ }^{1, *}$ \\ ${ }^{1}$ Department of Modern Languages, National Pingtung University of Science and Technology, Pingtung County, \\ Taiwan, R.O.C. \\ *Correspondence: Department of Modern Languages, National Pingtung University of Science and Technology, \\ Pingtung County, Taiwan, R.O.C. Tel: 886-0966-996-107. E-mail: minliecool@gmail.com
}

Received: August 11, 2017

Accepted: September 14, 2017 Online Published: October 25, 2017

doi:10.5430/wje.v7n5p39

URL: https://doi.org/10.5430/wje.v7n5p39

\begin{abstract}
Current research on second language (L2) anxiety solely deals with the vague fears. Those research results do not reflect L2 learners' real concerns or furthermore help them to reduce the "tension" rather than anxiety. The researcher considers the need to distinguish L2 writing tension from L2 writing anxiety. Furthermore, this study attempts to infuse the pragmatic aspect by adding two categories of questions related to actual situations and classroom activities to the Foreign Language Writing Anxiety Questionnaire (Tsai, 2012). The results of the Bivarited correlation tests show both the inter-category and intra-category reach the significant level at .05 or better. Thus, the New Foreign Language Writing Anxiety Questionnaire (NFLWAQ, Appendix 1) is formed. Notably, the L2 writing tension in this study is significantly higher than the foreign language writing anxiety in the overall group as well as every individual group at the significant level of .05 or better. The results indicate that the participants worry about real situations and classroom activities more than the vague fears from nowhere. The peer review activity is recognized as the least pressure source that L2 writing teachers might want to practice it from time to time to reduce students' tension.
\end{abstract}

Keywords: L2 writing tension; L2 writing anxiety; New Foreign Language Writing Anxiety Questionnaire (NFLWAQ); University students

\section{Introduction}

Most research related to foreign language anxiety and/or apprehension dealt with "vague fear" or abstract feelings of worries (Bailey, Daley, \& Onwuegbuzie, 1999; Brown, 1994; Cheng, 2002; Cheng, 2004; Horwitz, Horwitz, \& Cope, 1986; Lightbrown \& Spada, 2006; Scovel, 1978) that are more likely to be a state of "panic" or "phobia," illogical nervousness and stress. However, this study was more concerned about the tension (Spielmann \& Radnofsky, 2001) evoked from the worries of the real situations and experiences of classroom activities because this study started from a real classroom teaching practice and cared about the solid changes that could be made to reduce the students' anxiety or tension.

The researcher considers the need to distinguish the tension of L2 learners toward the actual classroom conditions and activities from the vague fears or abstract feelings of worries, the so-called "anxiety." When almost all the anxiety researchers flocked at the entrance gate of a Ferris wheel to ask people who were waiting in line for ridding the Ferris wheel about their feeling of anxiety, the researcher went to the exit door to explore those who had just stepped down from the Ferris wheel. The researcher was so shocked by the scene she had seen. Most were shaking and trembling, some cried out "terrifying," a few kissed the earth to thank God, and one or two kneed down to puke. Those L2 writing learners who experienced timed writing resembled the people just walking down from the Ferris wheel. The researcher felt the need to explore their "L2 writing tension." Thus, the researcher revised the Foreign Language Classroom Anxiety Scale (FLCAS that mainly deals with listening skill) (Horwitz, Horwitz, \& Cope, 1986) and Tsai's study in 2012 plus two new categories of L2 tension questions to form the "New Foreign Language Writing Anxiety Questionnaire (NFLWAQ) (Appendix 1)." The NFLWAQ consists of 42 questions that are classified into seven categories, namely General Worries (GW), Class Performance (CP), Pressure from Teacher (PFT), Peer Pressure (PP), Language difficulties (LD), Real Situations (RS) and Classroom Activities (CA). The first five categories, GW, CP, PFT, PP and LD, are the Foreign Language Writing Anxiety Questionnaire (FLWAQ) (Tsai, 2012), whereas, the last two categories, RS and CA, are the Foreign Language Writing Tension Questionnaire 
(FLWTQ) in this study. All together, they are comprised to form the New Foreign Language Writing Anxiety Questionnaire (NFLWAQ).

A researcher-made questionnaire (Table 9) comprised of fourteen actual classroom practices was designed to explore the participants' tension. The researcher also composed the Ways to Reduce Writing Tension Questionnaire (Table 15). Besides, owing to the last time success of creating a new category, language difficulties, and incorporating it (Table 6) to the revised Foreign Language Classroom Anxiety Scale (FLCAS) (Horwitz, Horwitz, \& Cope, 1986) in Tsai's study (2012), the attempt was made again to expand and enrich the FLCAS in the practical aspect and the pragmatic scope. All the question items in Table 6 were again reconfirmed to be significantly correlated at the .05 level or better on the correlation tests of intra-category or inter-category and factor analysis, excluding two question items (Q3 and Q5) in the General Worries category.

\section{Literature Review}

\subsection{Definition of Anxiety and Tension}

Horwitz, Horwitz, \& Cope (1986) defined that anxiety is the subjective feeling of tension, apprehension, nervousness, and worry associated with an arousal of the autonomic nervous system (p.352). Ellis (1994) classified anxiety into three types: Trait, state and situation-specific anxiety. Trait anxiety is a more permanent disposition to be anxious, is viewed as an aspect of personality. State anxiety is an apprehension that is experienced at a particular moment in time as a response to a definite situation. Lastly, situation-specific anxiety is related to apprehension aroused at specific situations and events.

Gardner \& MacIntyre (1993) described language anxiety as the apprehension experienced when a situation requires the use of L2 with which the individual is not fully proficient. Therefore, L2 anxiety is thought to be a situation-specific anxiety. Horwitz \& Young (1991) contended language anxiety had three varieties: Communicative apprehension, fear of negative evaluation, and test anxiety. Communicative apprehension occurs when learners have immature communication skills although they have mature ideas and thoughts. It is a fear about real communication with others. Fear of negative evaluation occurs when L2 learners feel that they are not able to make the proper social impression. It is an apprehension about others' evaluation, avoidance of evaluative situations, and the expectation. Test anxiety is an apprehension over academic evaluation. It is a fear of failing in test situations and an unpleasant experience held consciously or unconsciously by learners in many situations. It is a type of anxiety concerning apprehension over academic evaluation which comes from a fear of failure (Horwitz \& Young, 1991, cited by Aydin, 2007). Young (1991) claimed Horwitz, Horwitz, \& Cope (1986) were the first to treat foreign language anxiety (FLA) as a separate and distinct phenomenon particular to language learning (p. 427). Trang (2012) echoed that Horwitz, Horwitz, \& Cope were the first to conceptualize FLA as a unique type of anxiety specific to foreign language learning. Their theoretical model of FLA plays a vital role in language anxiety research that has made them influential researchers in this area (p.69).

Spielmann \& Radnofsky (2001) defined tension as "an unstable phenomenon that may be generated by any situation or event and may be perceived differently by each individual experiencing it." They also suggested that "students reacted most productively not to the degree of difficulty and expectation in the course, or to the reduction of affective dysphoria (anxiety) by a non-threatening teaching style, but to the quality of materials and activities."

Anxiety would be amnestied, dismissed, and forgotten after students realized their eventual achievement in the language program.

\subsection{Anxiety Scales}

According to Lee (2005), Daly, J. A., \& Miller, M. D. (1975a, 1975b) were the first to create a questionnaire to explore participants' anxiety (the Writing Apprehension Scale). They also concluded writing apprehension was most likely to develop from past negative experiences such as teacher's low expectation, evaluation, and excessive error corrections. Daly \& Miller's Writing Apprehension Scale (1975a, 1975b) and Rose's Writer's Block Questionnaire (1984) were adopted by Lee (2005) to investigate 270 university students in Taiwan for testing her Structural Equation Modeling (SEM) which contained both facilitating and inhibiting factors. Her research results showed that free voluntary reading was the only significant predictor of students' writing performance. That is, writing apprehension, writer's block, free writing, and attitudes toward instruction were not significantly facilitating/inhibiting factors of writing performance.

Horwitz, Horwitz, \& Cope's Foreign Language Classroom Anxiety Scale (FLCAS) (1986) dominates the L2 and EFL anxiety studies for more than 30 years up to the present time. In their famous and most cited study (Horwitz, 
Horwitz, \& Cope, 1986), the 33-item FLCAS hadn't been divided into subscales. However, they did mention that three related performance anxiety within academic and social context were communication apprehension, test anxiety, and fear of negative evaluation (p. 127). Horwitz, Horwitz, \& Cope (1986) investigated 75 university level students and claimed that the test-retest reliability of FLCAS over eight week yielded an $r=.83(p<.001)$ and the interval reliability achieved an alpha coefficient of .93 (p.129). However, Trang (2012) challenged Horwitz, Horwitz, \& Cope's theory of foreign language anxiety (FLA) with four points: a) the direction of the casual relationship between FLA and language learning difficulties; b) the important role of FLA; c) the components of FLA; and d) the validity of the FLCAS (p. 71). Trang (2012) cited Sparks \& Ganschow's notion (2007) that FLA was not likely to be a primary cause of problems with foreign language learning. Thus, they had had doubt on the importance attributed to FLA in foreign language learning. Trang (2012) also advocated Spielmann \& Radnofsky's suggestion (2001) that anxiety research should shift the focus from anxiety to tension (p. 72).

Sparks \& Ganschow (2007) reported their over-ten-year longitudinal study. In that study, they divided 54 students into low, average, and high anxiety groups based on Horwitz, Horwitz, \& Cope's FLCAS. The participants were tested native and foreign language skills by many kinds of measures including Modern Language Aptitude Test (MLAT), FLCAS, Foreign Language Proficiency Test, Foreign Language Grade-Year 1, Foreign Language Grade-Year 2, Woodcock Reading Mastery Test, Test of Written Spelling, Formal Reading Inventory, Peabody Picture Vocabulary Test, Test of Cognitive Skills, Listening Comprehension Test, Foreign Language Word Decoding, and Foreign Language Spelling, etc. The research results re-assured their previous findings in 1991 and 1995 that (1) foreign language anxiety is likely to be related to a student's native language learning skills, (2) foreign language anxiety is likely to be a consequence of a student's level of native language learning, (3) early native language skills even in elementary school serve as an important foundation for foreign language learning in high school, and (4) language learning skills play a confounding role in theories that suggest that anxiety plays a primary role in foreign language proficiency and achievement (p.279). Sparks \& Ganschow also claimed that the FLCAS is in large part measuring students' self-knowledge of their language learning skills (p.279).

MacIntyre and Gardner (1989) used nine anxiety scales, including French Class Anxiety Scale, English Class Anxiety Scale, Mathematics Anxiety Scale, French Use Anxiety Scale, Trait Anxiety Scale, Computer Anxiety Scale, State Anxiety Scale, Test Anxiety Scale, and Audience Anxiety Scale to examine the relationship between the dimensions of anxiety and the various measures of learning and production, including oral and written scores.

Cheng's study (2004b) tested and re-tested the validity and reliability of her Second Language Writing Anxiety Inventory (SLWAI). She furthermore adopted ten instruments to examine the correlation coefficient between SLWAI and the existing scales. The ten scales she used were: English Use Anxiety Scale, English Classroom Anxiety Scale (ECAS), English Writing Apprehension/Attitude Test (EWAT), English Writing Block Questionnaire (EWBQ), English Writing Self-efficacy Scale (EWSS), Personal Report of Communication Apprehension-College (PRAC-C), Test Anxiety Scale (TAS), Math Anxiety Scale (MAS), English Writing Motivation Scale (EWMS), State Anxiety Scale (SAS), and Index of English Writing Performance. However, her three subscales: somatic anxiety, avoidance behavior, and cognitive anxiety did not include the instructional practices nor classify it as a category that she discovered in another study in the same year (Cheng, 2004a). In that study she concluded that student writers' anxiety might stem from a variety of sources related to a) instructional practices, b) personal beliefs about writing and learning to write, c) self-perceptions, and d) interpersonal threats (Cheng, 2004a). Thus, the Second Language Writing Anxiety Inventory (SLWAI) is mainly thought to deal with abstract feeling of anxiety or a phenomenon that is therefore hard to be logically connected to the practical classroom measures/means to reduce the evoked anxiety.

Choi (2013) used a revised Foreign Language Classroom Anxiety Scale and the English Writing Anxiety Scale (EWAS) (Lee, 2005) to measure 26 Korean junior high school students' free writing portfolio and found two scales are significantly correlated. The participants in Choi's study (2013) identified the sources of English writing anxiety: $50.2 \%$ of the participants were afraid that they might make grammatical mistakes in English writing; $15.3 \%$ were due to insufficient vocabulary knowledge; $13.4 \%$ were because of the lack of confidence and anxiety; while $21.1 \%$ comprised a number of various reasons (p. 12). Choi (2013) also suggested using collaborative writing to decrease L2 writing anxiety just as Shehadeh (2011) did.

\subsection{Tension}

Spielmann \& Radnofsky's study (2001) shifted their focus to tension, and that involved 30 students (aged from the late teens to the late 20s) joining in an intensive 7-week French immersion program in the Middlebury College Language Schools where are in a rural and isolated location, and which are known for creating an unusually high level of pressure in and out of the classroom, through a L2-only written pledge, full immersion, rapid pace of 
instruction, and the challenges posed by high-caliber peers as well as by expectations of teachers (p. 5). The participants in the FR101 (full beginners) received the Naturalist, Communicative, and constructivist teaching methods and were encouraged to interact with the surrounding informants and went to a lot of "pericurriculum," such as lectures, films, plays, team sports, choir, cabaret, folk singing, study breaks, etc. In contrast, the subjects in the FR201 (false beginners) were taught with the Direct Method and the Audio-Lingual Method. A lot of homework, assignments, exercises, and drill practices prevented the FR 201 students from going to the extra-curriculums and interacting with the surrounding informants. Spielmann \& Radnofsky found that both groups evoked euphoric and dysphoric tension. The ideal goal of a pedagogical program should not be to limit itself to reducing affective dysphoric tension, but perhaps more importantly, to seek to maximize cognitive euphoric tension in order to obtain an optimal self-directed absorption that will eventually induce affective euphoria. From Spielmann \& Radnofsky's point of view, anxiety and stress are neither one-dimensional variables nor inherent to a person or situation, and simply reducing or suppressing them does not constitute an end in itself (p. 17). They also believed when students achieved certain level of L2 competency or proficiency, they would eventually forget the tension they had experienced. Besides, the role of L2 tension in language acquisition was less predictable than they anticipated. As a result, they suggested a new direction for future research which is to explore the quality of one's experience as an emerging Other - the wondrous metamorphosis that acquiring a new language is supposed to induce: The so-called "L2 self" in Spielmann \& Radnofsky's term.

\subsection{Causes of Writing Anxiety}

Cheng (2004a) found students' writing anxiety stem from instructional practices, personal beliefs about writing and learning to write, self-perceptions, and interpersonal threats. Rezaei \& Jafari (2014) used self-made Causes of Writing Anxiety Inventory (CWAI) to investigate 120 EFL students in two institutes in Iran and found that the top three causes of L2 writing anxiety were fear of teacher's negative comments, low self-confidence in writing, and linguistic difficulties.

Nosratinia \& Abdi (2017) compared 70 intermediate-level EFL learners' writing anxiety and found that the participants assessed with traditional summative method had significantly higher anxiety levels than those who were assessed with portfolio approach.

Jebreil, Azizifar, \& Gowhary (2015) found male participants in their study might experience relatively greater amount of cognitive anxiety than female participants, especially in grammar and punctuation. On the contrary, Kirmızı \& Kirmız (2015) found the male students in their study suffered less from writing anxiety because they had higher levels of writing self-efficacy. They also suggested the major causes of writing anxiety were time pressure and the negative evaluation from the teacher. In view of the above research findings, the researcher decided an anxiety questionnaire should include the seven categories as mentioned in the introduction section of this study.

\subsection{Ways to Reduce Anxiety}

Sulaiman Hasan Hussein Qashoaa's (2014) findings indicated that high levels of writing anxiety could primarily be attributed to writing tests, cognitive and linguistic factors. Qashoaa interviewed 10 highly anxious students and ten low anxious ones and a focus group discussion with 6 instructors to explore their perspectives on coping strategies. He provided the extracts of those alleviating Strategies.

Alrabai (2014) adopted anxiety-reducing strategies to ease the foreign language fears of 465 volunteer English learners aged from 18 to 25 and above. He concluded those strategies were significantly effective. The anxiety-reducing strategies consisted of: a) demonstrate proper teaching behavior to students; b) reduce learner communication apprehension; c) reduce the fear of negative evaluation in learners; d) reduce the fear of language testing in learners; e) properly address learner anxiety-provoking beliefs and misconceptions; f) help students establish specific and realistic goals for learning English; and g) increase students' self-confidence (p.11).

Cheng's (2004a) suggestions in alleviating writing anxiety included: provide options of writing topics and the composing approach; avoid timed writing; make uses of email and chat room communication activities as well as journal writing and project writing to foster frequency; allow multiple drafts and less attention paid to grammar and mechanics; organizing brainstorming, pre-writing, and free writing activities; provide corrective feedback but avoid transmitting misconception of the role of errors in the process of learning to write; place a balanced emphasis on linguistic accuracy and meaningful content; involve students to develop evaluation criteria if possible; boost students' confidence by helping them focus more on what they can do than what they cannot do; and share our own struggles and anxiety in writing that may help relieve students' anxiety caused by their belief (p. 55-58).

Donley, Philip (1997) suggested ten ways to cope with foreign language anxiety. The proposed strategies for 
reducing foreign language anxiety in the classroom include: a) discuss feelings with instructor and other students; $b$ ) relax, exercise, and eat well; c) prepare for and attend every class; d) keep foreign language class in perspective; e) seek opportunities to practice the language and accept errors are a part of the learning process; and f) develop individual standards and rewards for success.

Young (1991) and Leki (1999) also proposed ways to reduce foreign language classroom anxiety, such as pair wok and group work, more games, tailor activities to the affective needs of the learners', don't call on students in class randomly, etc.

\section{Methods}

\subsection{Participants}

A total of 51 students of the Modern Languages Department in a University of Science and Technology in southern Taiwan participated in the study. The sophomores $(\mathrm{C} 1$ and $\mathrm{C} 2)$ in this study actually belong to the same class of the Modern Languages Department. However, because the department employs a small-group of writing teaching policy, they are divided into two classes according to the student ID numbers that the odd numbers go to one class, whereas the even numbers go to the other. Class 3 (C3) consists of 24 freshmen. Originally, there are respectively 24, 23, and 24 students in Class 1 (C1), Class 2 (C2), and Class 3 (C3). However, 17, 13 and 21, a total of 51, valid questionnaires were collected under study (Table 1). The sophomores were aged 20, while the freshmen were 19 years old. Of the 51 participants, 10 are male, while 41 are female. Additional information concerning the participants of this study, please refer to Table 3 and 4 .

Table 1. The Participants of the Study

\begin{tabular}{lcccc}
\hline \multicolumn{2}{c}{ Sophomores } & Freshman & \\
\hline Class & $\mathrm{C} 1$ & $\mathrm{C} 2$ & $\mathrm{C} 3$ & Total \\
\hline male & $4(7.8 \%)$ & $3(5.9 \%)$ & $3(5.9 \%)$ & $10(19.6 \%)$ \\
female & $13(25.5 \%)$ & $10(19.6 \%)$ & $18(35.3 \%)$ & $41(80.4 \%)$ \\
N of students & $17(33.3 \%)$ & $13(25.5 \%)$ & $21(41.2 \%)$ & $51(100.0 \%)$ \\
\hline
\end{tabular}

\subsection{The Research Design and Research Questions}

Based on the research design (Table 2), this study focused on examining the anxiety and tension differences in an attempt to explore the following research questions:

1. Does the foreign language writing anxiety differ among groups and what are the participants anxious about?

2. Does the L2 writing tension differ among groups and what caused the most and the least tension?

3. Is the foreign language writing tension induced from worries of real situations and actual classroom activities higher than the writing anxiety evoked by vague fears?

4. Does the Foreign Language Writing Tension Questionnaire fit in the Foreign Language Writing Anxiety Questionnaire to become the New Foreign Language Writing Anxiety Questionnaire (NFLWAQ)?

5. What are the ways to reduce $\mathrm{L} 2$ writing tension?

Table 2. The Research Design

\begin{tabular}{|c|c|c|c|c|c|}
\hline \multicolumn{6}{|c|}{ New Foreign Language Writing Anxiety Questionnaire } \\
\hline \multicolumn{3}{|c|}{ Anxiety } & \multicolumn{3}{|c|}{ Tension } \\
\hline \multicolumn{2}{|c|}{ Sophomores (SS) } & Freshmen (FS) & Sopho & es (SS) & Freshmen (FS) \\
\hline $\mathrm{C} 1$ & $\mathrm{C} 2$ & $\mathrm{C} 3$ & $\mathrm{C} 1$ & $\mathrm{C} 2$ & $\mathrm{C} 3$ \\
\hline
\end{tabular}

\subsection{Instrument}

The participants in this study were investigated with the Foreign Language Writing Anxiety Questionnaire (Table 6), the L2 Writing Tension Questionnaire (Table 9), and the Ways to Reduce L2 Writing Tension Questionnaire (Table 15). After the questionnaires were collected, the statistical program, SPSS 12.0 and Excel, were used to carry out the ANOVA, independent-sample t tests, paired-sample tests, and drew Figure 1. The Foreign Language Writing Anxiety Questionnaire and the L2 Writing Tension Questionnaire were both researcher-made questionnaires. The former was 
adopted and revised from the Foreign Language Classroom Anxiety Scale (FLCAS) (Horwitz, Horwitz, \& Cope, 1986), and some items were reversely constructed to ensure correct cording (Tsai, 2012), whereas the latter was designed for this study to infuse a practical aspect of anxiety, namely tension, by adding two categories of questions into the former. The last, the Ways to Reduce L2 Writing Tension Questionnaire was used to recognize the participants' perception of methods of reducing L2 writing tension.

\subsection{Procedure}

All the participants in this study finished an 18-week Writing II (freshmen) or Writing IV (sophomores) class and took the Foreign Language Writing Anxiety Questionnaire, the L2 Writing Tension Questionnaire, and the Ways to Reduce L2 Writing Tension Questionnaire. After the data were collected, the researcher first examined FLWAQ results to see if the foreign language anxiety differ among groups and what the participants anxious about. Second, the FLWTQ results were analyzed to find out if the foreign language writing tension differences exists among groups. Then, the FLWAQ results were compared with FLWTQ results to see if the foreign language writing tension induced from worries of real situations and actual classroom activities is higher than the writing anxiety evoked by vague fears. Fourth, the researcher examined whether the FLWTQ fitted in the Foreign Language Writing Anxiety Questionnaire. If they significantly correlated to each other, they would be combined together to form the New Foreign Language Writing Anxiety Questionnaire (NFLWAQ). Finally, the researcher sought ways to reduce the participants' L2 writing tension.

\section{Findings and Discussions}

\subsection{Gender Difference}

Before getting started to answer our research questions, variables such as study year or age, gender, having taken proficiency test, family income, perceived L2 proficiency, and language difficulty areas (Table 3 and 4) were examined to see if they were related to writing anxiety and/or tension at the significant levels. Regarding the perceived difficulties in learning English, some participants checked more than one item, for instance, a participant might indicate he/she had problems both in grammar and structure \& style. Therefore, the count exceeded the actual number of participants ( 41 responses in the language difficulties category in Table 3 and 23 responses in the same category in Table 4).

Table 3. Participants of the Sophomore Writing Class

\begin{tabular}{ccccccccccc}
\hline & \multicolumn{2}{c}{ gender } & \multicolumn{2}{c}{ income } & \multicolumn{2}{c}{ proficiency } & \multicolumn{2}{c}{ Taken test } & \multicolumn{2}{c}{ difficulties } \\
\hline coding & $\mathrm{N}$ & $\%$ & $\mathrm{~N}$ & $\%$ & $\mathrm{~N}$ & $\%$ & $\mathrm{~N}$ & $\%$ & $\mathrm{~N}$ & $\%$ \\
\hline 1 & 7 & 23.3 & 11 & 45.8 & 0 & 0.0 & 4 & 13.3 & 1 & 2.4 \\
2 & 23 & 76.7 & 5 & 20.8 & 11 & 36.7 & 26 & 86.7 & 13 & 31.7 \\
3 & & & 3 & 12.5 & 17 & 56.7 & & & 3 & 7.3 \\
4 & & & 2 & 8.3 & 2 & 6.7 & & & 13 & 31.7 \\
5 & & & 0 & 0.0 & & & & & 0 & 0 \\
6 & & & 2 & 8.3 & & & & & 4 & 9.8 \\
7 & & & 1 & 4.2 & & & & & \\
Total & 30 & 100.0 & 24 & 100.0 & 30 & 100.0 & 30 & 100.0 & 41 & 100.0 \\
Missing & & & 6 & & & & & & & \\
\hline
\end{tabular}

Table 4. Participants of the Freshman Writing Class

\begin{tabular}{ccccccccccc}
\hline & \multicolumn{2}{c}{ gender } & \multicolumn{2}{c}{ income } & \multicolumn{2}{c}{ proficiency } & \multicolumn{2}{c}{ Test taken } & \multicolumn{2}{c}{ difficulties } \\
\hline \multicolumn{1}{c}{ coding } & $\mathrm{N}$ & $\%$ & $\mathrm{~N}$ & $\%$ & $\mathrm{~N}$ & $\%$ & $\mathrm{~N}$ & $\%$ & $\mathrm{~N}$ & $\%$ \\
\hline 1 & 3 & 14.3 & 8 & 53.3 & 0 & 0.0 & 1 & 4.8 & 3 & 13.0 \\
2 & 18 & 85.7 & 3 & 20.0 & 9 & 45.0 & 20 & 95.2 & 9 & 39.1 \\
3 & & & 1 & 6.7 & 11 & 55.0 & & & 2 & 8.7 \\
4 & & & 1 & 6.7 & & & & & 6 & 26.1 \\
5 & & & 0 & 0.0 & & & & & 3 & 13.0 \\
6 & & & 1 & 6.7 & & & & & & \\
7 & & & 1 & 6.7 & & & & & \\
total & 21 & 100.0 & 15 & 100.0 & 20 & 100.0 & 21 & 100.0 & 23 & 100.0 \\
Missing & & & 6 & & 1 & & & & & \\
\hline
\end{tabular}


When independent-sample $t$ test was carried out, the results showed that neither the study year nor having taken proficiency test significantly differed in writing anxiety or tension levels. The study year or age (sophomores and the freshmen in this case) did not significantly differ on the anxiety level that was consistent with Cheng's study (2002). However, in Cheng's study, the female experienced higher writing anxiety than the male. In the study, gender difference was significantly related to only Q8, and Q29 in the writing anxiety questionnaire, but not related to the writing tension (Table $5 \& 6$ ). That is, the female students in this study had higher anxiety (vague fears) than the male when practiced English writing at home and felt overwhelmed by the number of rules they had to learn to write essays (Table 6). When one-way ANOVA was performed, none of the family income, the perceived L2 proficiency, and/or the L2 difficulty area significantly differed in both writing anxiety and tension levels.

In this study, the $\mathrm{C} 1$ class wrote essays in class, therefore, their writing anxiety level at home is relatively much lower than the $\mathrm{C} 2$ and $\mathrm{C} 3$ classes. However, $\mathrm{C} 1$ teacher consistently followed the textbook and requested students to write and underline certain training objectives such as the hook, the topic sentence, the supporting information, the conclusion, the connectors, etc. for the teacher to grade on. Thus, female students felt overwhelmed by the number of rules they had to learn to write essays (Q29).

Table 5. Independent-Sample Test of Gender Difference on Q8 and Q29 in FL Writing Anxiety

\begin{tabular}{|c|c|c|c|c|c|c|c|c|c|}
\hline \multirow[b]{3}{*}{ Q8 \& Q29 } & \multicolumn{4}{|c|}{$\begin{array}{l}\text { Levene's test } \\
\text { for Equality } \\
\text { of Variances }\end{array}$} & \multicolumn{5}{|c|}{$\mathrm{T}$ test for the Equality of Means } \\
\hline & \multirow[b]{2}{*}{$\mathrm{F}$} & \multirow[b]{2}{*}{ Sig. } & \multirow[b]{2}{*}{$\mathrm{t}$} & \multirow[b]{2}{*}{$\mathrm{df}$} & \multirow{2}{*}{$\begin{array}{c}\text { Sig. } \\
\text { (2 tailed) }\end{array}$} & \multirow{2}{*}{$\begin{array}{l}\text { Mean } \\
\text { Diff. }\end{array}$} & \multirow{2}{*}{$\begin{array}{l}\text { STD } \\
\text { Error } \\
\text { Diff. }\end{array}$} & \multicolumn{2}{|c|}{$\begin{array}{l}\text { 95\% Confidence } \\
\text { interval } \\
\text { of the Difference }\end{array}$} \\
\hline & & & & & & & & lower & upper \\
\hline $\begin{array}{l}\text { Eql vari. } \\
\text { assumed }\end{array}$ & $\begin{array}{c}10.5 \\
5\end{array}$ & .002 & -2.10 & 47 & .041 & -.459 & 10.55 & .002 & -2.10 \\
\hline $\begin{array}{l}\text { Eql vari. not } \\
\text { assumed }\end{array}$ & & & -3.13 & 31.6 & .004 & -.459 & & & -3.13 \\
\hline $\begin{array}{l}\text { Eql vari. } \\
\text { assumed }\end{array}$ & .95 & .334 & -2.62 & 47 & .012 & -.65 & .25 & -1.14 & -.15 \\
\hline $\begin{array}{l}\text { Eql vari. not } \\
\text { assumed }\end{array}$ & & & -2.38 & 12.5 & .034 & -.65 & .27 & -1.24 & -.06 \\
\hline
\end{tabular}

4.2 Findings of Research Question 1: Does the foreign language writing anxiety differ among groups and what are the participants anxious about?

Table 6 lists the questions and the results of the foreign language writing anxiety sorted by categories and subject groups. The results are summarized in the follows:

1. Inter-group:
a. $\mathrm{SS}>\mathrm{FS}$
b. $\mathrm{C} 1>\mathrm{C} 3>\mathrm{C} 2$

2. Inter-category:
a. $\mathrm{C} 1: \mathrm{LD}>\mathrm{CP}>\mathrm{PP}>\mathrm{SFT}>\mathrm{GW}$
b. $\mathrm{C} 2: \mathrm{LD}>\mathrm{PP}>\mathrm{GW}>\mathrm{CP}>\mathrm{SFT}$
c. $\quad$ SS: $\mathrm{LD}>\mathrm{PP}>\mathrm{CP}>\mathrm{GW}>\mathrm{SFT}$
d. $\quad$ FS: $\mathrm{LD}>\mathrm{GW}>\mathrm{PP}>\mathrm{SFT}>\mathrm{CP}$
e. All: $\mathrm{LD}>\mathrm{PP}>\mathrm{GW}>\mathrm{CP}>\mathrm{SFT}$

3. Intra-group:
a. $\mathrm{C} 1: \mathrm{Q} 1>\mathrm{Q} 10, \mathrm{Q} 12,26, \mathrm{Q} 31>\cdots>\mathrm{Q} 8$
b. $\mathrm{C} 2: \mathrm{Q} 1, \mathrm{Q} 12>\mathrm{Q} 30>\mathrm{Q} 26,28,31>\cdots>\mathrm{Q} 18$ 


$$
\begin{array}{ll}
\text { c. } & \text { SS: Q1 }>\text { Q12 }>\text { Q26, Q31 }>\text { Q30 }>\cdots>\text { Q8 } \\
\text { d. } & \text { FS: Q2 }>\text { Q31 }>\text { Q6, Q28 }>\text { Q10, Q26, Q29, 30 }>\cdots>\text { Q23 } \\
\text { e. } & \text { All: Q31 }>\text { Q1, Q2 }>\text { Q12, 26 }>\cdots>\text { Q8, Q18, Q23 }
\end{array}
$$

The sophomore students have higher anxiety than the freshman students. C1 class has the highest anxiety level, followed by $\mathrm{C} 3$ and $\mathrm{C} 2$. Regarding the inter-category results, a pattern seems to emerge that all the groups identify language difficulties (LD) inducing the highest anxiety and stress from teacher (SFT) causing the least anxiety. However, $\mathrm{C} 1$ deems General Worries having the least pressure, while Freshmen (C3) considered Class Performance (CP) having the least anxiety.

In an informal interview with the teachers, the researcher learned that $\mathrm{C} 1$ students practiced five compositions in class in 18 weeks including two narrative essays, one comparative essay, one cause \& effect essay, one argumentative essay, and two grammar tests (the grammatical errors were collected from the students' compositions) as the midterm and the final exam, while $\mathrm{C} 2$ students wrote two compositions as the midterm and the final exam and two outlines of different essays. The freshman students (C3) practiced paragraph writing. In this study, $\mathrm{C} 1$ and $\mathrm{C} 2$ used the same writing textbook. Therefore, the classroom activities, the in-class writing tasks, should be the main reason that caused high writing anxiety. Piniel (2006) attributed the foreign language writing anxiety to the role of teacher, whereas Spielmann \& Radnofsky (2001) suggested the quality teaching materials and classroom activities were accounted for class success. In this case, conducting the foreign language writing anxiety questionnaire (Table 6) as a pre-test before the students get the syllabi and learn what they are going to do in class in the whole semester could be a way to find out whether the anxiety is caused by in-class task pressure. And the L2 writing tension questionnaire (Table 9) can be managed as a post-test. Just as Cheng pointed out in 2002, anxiety tests before and after a writing task help to explain the development of L2 writing anxiety.

From the intra-group results, the sophomores consider the fear of writing in class (Q1) has the highest anxiety, whereas the freshmen most worry about the consequence of failing the writing class (Q2). In the overall group, Q31: writing without any concept of structure and style in mind brings about the highest anxiety. By and large, Q8, Q18 and Q23 evoke the least anxiety. Q8: I feel not confident when I practice English writing at home; Q18: I feel more tense and nervous in my writing class than in my other classes; and Q23: I am afraid that my writing teacher is ready to correct every mistake I make. The reasons of the lease anxiety on Q8 and Q18 are that all three writing teachers request students to write in class, relatively, writing at home do not cause too much anxiety; and the foreign language writing class is probably not the most stressful course compared with the foreign language spoken class. The Q23 result is interpreted that the participants generally consider corrections are helpful and do not induce much anxiety. But evaluation does induce anxiety because it involves ranking, rating, or giving scores.

The intra-category and inter-category on the correlation tests and the factor analysis all reach the significant .05 level or better, except Q3 and Q5 in the General Worries category. The inter-groups of the foreign language writing anxiety are tested by the independent-Sample $\mathrm{t}$ Test and the results indicate that the differences exist between $\mathrm{C} 1$ and $\mathrm{C} 2$, as well as $\mathrm{C} 1$ and $\mathrm{C} 3$ at the significant the .001 and the .01 level respectively (Table 7, and 8), whereas the anxiety difference of $\mathrm{C} 2$ and $\mathrm{C} 3$ do not reach the significant level. The sophomores and freshmen anxiety levels didn't differ

\begin{tabular}{|c|c|c|c|c|c|}
\hline & $\mathrm{C} 1$ & $\mathrm{C} 2$ & SS & FS & ALL \\
\hline General Worries (GW) & 2.69 & 2.51 & 2.61 & 2.61 & 2.61 \\
\hline $\begin{array}{l}\text { 1. I never feel quite sure of myself when I am writing in } \\
\text { class. }\end{array}$ & 3.07 & 2.92 & 3.00 & 2.57 & 2.85 \\
\hline $\begin{array}{l}\text { 2. I worry about the consequences of failing this writing } \\
\text { class. }\end{array}$ & 2.87 & 2.62 & 2.75 & 2.90 & 2.80 \\
\hline $\begin{array}{l}\text { 4. In language classes, I can get so nervous I forget things I } \\
\text { know. }\end{array}$ & 2.87 & 2.15 & 2.51 & 2.57 & 2.53 \\
\hline 6. I would be nervous writing to native speakers. & 2.67 & 2.62 & 2.65 & 2.81 & 2.70 \\
\hline $\begin{array}{l}\text { 7. The more I study for a language test, the more confused I } \\
\text { get. }\end{array}$ & 2.60 & 2.31 & 2.46 & 2.52 & 2.48 \\
\hline $\begin{array}{l}\text { 8. I feel not confident when I practice English writing at } \\
\text { home. }\end{array}$ & 2.07 & 2.46 & 2.27 & 2.29 & 2.27 \\
\hline
\end{tabular}
significantly, either.

Table 6. Foreign Language Writing Anxiety Questionnaire Results (FLWAQ) by Group 
Class Performance (CP)

9. I am usually at unease during tests in my writing class.

10. I worry about making mistakes in the writing class.

11. It would bother me very much to take more writing classes.

12. I get nervous when the writing teacher asks me to write what I haven't prepared in advance.

13. I feel pressure to prepare very well for the writing class.

14. Even if I am well prepared for the writing class, I feel anxious about it.

15. I often feel like not going to my writing class.

16. I can feel my heart pounding when I'm going to be called on to make sentences in the writing class.

17. The writing class moves so quickly I worry about getting left behind.

18. I feel more tense and nervous in my writing class than in my other classes.

19. When I'm on my way to the writing class, I feel very uneasy and unsure.

Stress from the Teacher (SFT)

20. I get nervous when I don't understand every word the writing teacher says.

21. I tremble when I know that I'm going to be called on in writing class. teacher is correcting.

23. I am afraid that my writing teacher is ready to correct every mistake I make.

Peer Pressure (PP)

24. I am afraid that the other students will laugh at my writing.

25. I keep thinking that the other students are better at languages than I am.

26. I always feel that the other students write better than I do.

27. I feel very self-conscious about my articles being read by other students.

Language Difficulties (LD)

28. I start to panic when I misspell in writing.

29. I feel overwhelmed by the number of rules I have to learn to write essays.

30. It embarrasses me to write in class when I make mistakes of tenses.

31. I get nervous and confused when I write without any concept of structure and style in mind.
22. I get upset when I don't understand what the writing

2.79

2.80

3.00

2.73

3.00

2.73

2.67

2.73

2.87

2.93

2.53

2.6

2.67

2.67

2.80

2.29

2.31

2.48

2.56

2.87

2.53

2.3

2.47

2.38

2.60

2.46

2.15

2.3

2.19

2.27

2.70

2.5

2.93

3.00

2.33

2.60

2.65

2.5

2.54

2.61

2.62

2.62

2.78

2.62

2.69

2.54

2.85

2.71

$2.44 \quad 2.43$

2.80

2.43

\subsection{5}

2.67

2.67

2.76

2.69

2.68

2.77

2.76

2.93

2.46

2.70

$2.81 \quad 2.72$

2.80

2.85

2.83

2.71

2.79

3.00

2.69

2.85

2.86

2.85

$\begin{array}{lllll}2.74 & 2.49 & 2.62 & 2.58 & 2.60\end{array}$

Average

Q3 and Q5 were removed from the Questionnaire because of insignificant correlation within group.
I don't understand why some people get so upset over writing classes.

5. During language class, I find myself thinking about things $\quad \begin{array}{lllll}2.80 & 2.46 & 2.63 & 2.62 & 2.63\end{array}$ that have nothing to do with the course. 
Table 7. Independent-Sample Test of the Foreign Language Writing Anxiety Difference of C1 and C2

\begin{tabular}{|c|c|c|c|c|c|c|c|c|c|}
\hline & \multicolumn{4}{|c|}{$\begin{array}{l}\text { Levene's test } \\
\text { for Equality } \\
\text { of Variances }\end{array}$} & \multicolumn{5}{|c|}{ T test for the Equality of Means } \\
\hline & \multirow[b]{2}{*}{$\mathrm{F}$} & \multirow[b]{2}{*}{ Sig. } & \multirow[b]{2}{*}{$\mathrm{t}$} & \multirow[b]{2}{*}{$\mathrm{df}$} & \multirow{2}{*}{$\begin{array}{c}\text { Sig. } \\
(2 \text { tailed })\end{array}$} & \multirow{2}{*}{$\begin{array}{l}\text { Mean } \\
\text { Diff. }\end{array}$} & \multirow{2}{*}{$\begin{array}{l}\text { STD } \\
\text { Error } \\
\text { Diff. }\end{array}$} & \multicolumn{2}{|c|}{$\begin{array}{c}95 \% \text { Confidence interval } \\
\text { of the Difference }\end{array}$} \\
\hline & & & & & & & & lower & upper \\
\hline $\begin{array}{l}\text { Eql vari. } \\
\text { assumed }\end{array}$ & .25 & .875 & 4.542 & 60 & .000 & .2746 & .0605 & .1537 & .3956 \\
\hline $\begin{array}{l}\text { Eql vari. not } \\
\text { assumed }\end{array}$ & & & 4.542 & 59.992 & .000 & .2746 & .0605 & .1537 & .3956 \\
\hline
\end{tabular}

Table 8. Independent-Sample Test of the Foreign Language Writing Anxiety Difference of C1 and C3

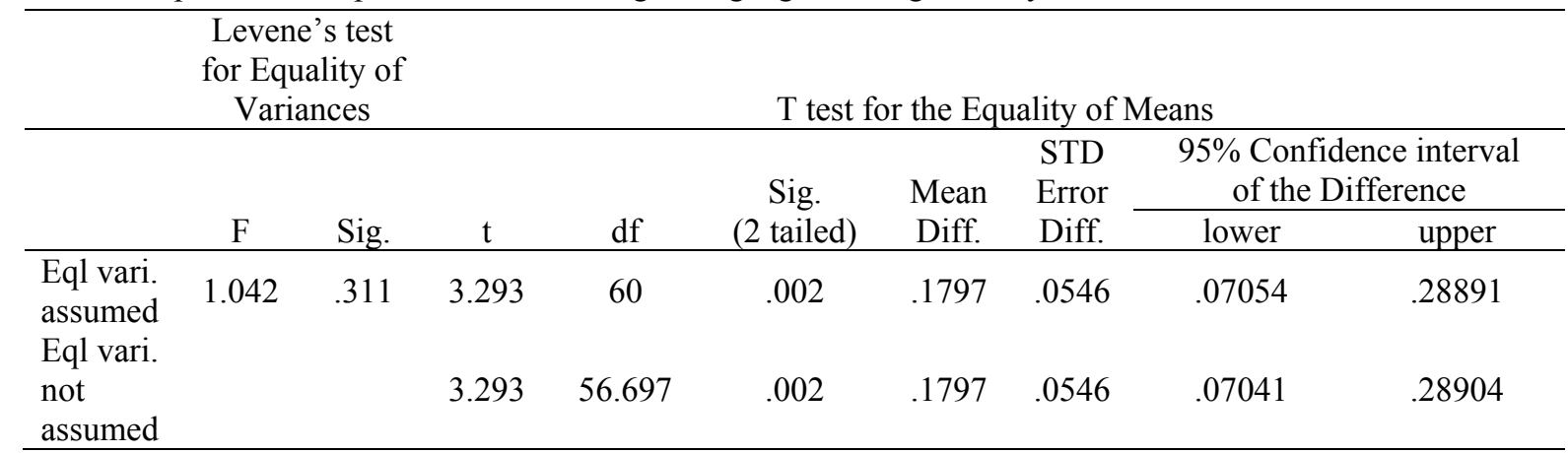

4.3 Findings of Research Question 2: Does the L2 Writing Tension Differ among Groups and What Caused the Most and the Least Tension?

Table 9 shows the L2 writing tension among groups. The results are summarized in the follows:

1. Inter-group:
a. $\mathrm{SS}(\mathrm{C} 1+\mathrm{C} 2)>\mathrm{FS}$
b. $\mathrm{C} 1>\mathrm{C} 2>\mathrm{C} 3$

2. Intra-group:

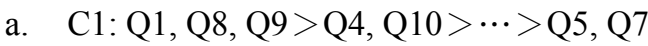
b. $\mathrm{C} 2$ : Q2, Q3, Q4>Q1, Q8> $>>$ Q7
c. $\quad \mathrm{SS}: \mathrm{Q} 1, \mathrm{Q} 4, \mathrm{Q} 8>\mathrm{Q} 2, \mathrm{Q} 9>\cdots>\mathrm{Q} 7$
d. $\quad$ FS: Q9 $>$ Q10 $>$ Q3 $>$ Q2, Q4, Q8 $>\cdots>$ Q7
e. All: Q9>Q4, Q8>Q1, Q2, Q3, Q10 $>\cdots>$ Q7

As shown on Table 12, the sophomores have higher L2 writing tension than the freshmen, and C1 has the highest writing tension, followed by $\mathrm{C} 2$, then $\mathrm{C} 3$. Among items, $\mathrm{C} 1$ worries the most about making grammatical errors (Q1), having no idea what to write about (Q8), and poor grades on compositions (Q9). C2 first worries about wrongly using words, style and structure, and insufficient time (Q2, Q3, and Q4); while C3 feels the biggest tension on poor grade on composition (Q9), followed by poor grades on midterm and final exam (Q10), then wrong style and structure (Q3). Poor grade on composition (Q9) is the most worried item in the overall group, followed by the worries of writing with limited time (Q4) and having no idea what to write about (Q8). Throughout the groups, the participants least worried about peer review (Q7) as well as having no options for the writing topic (only in C1). Therefore, peer review seems to be an effective teaching strategy to be used in writing class for reducing L 2 writing tension. 
4.4 Findings of Research Question 3: Is the Foreign Language Writing Tension Induced from Worries of Real Situations and Actual Classroom Activities Higher than the Writing Anxiety Evoked by Vague Fears?

This study adopts Spielmann \& Radnofsky's definition (2001) that tension is "an unstable phenomenon that may be generated by any situation or event and may be perceived differently by each individual experiencing it." The questions of foreign language writing anxiety associated with vague fears are presented in Table 6, while the L2 writing tension questions related to practical situations and classroom activities are displayed in Table 9. The results of differences are summarized in Table 10 that reveals the L2 writing tension levels are all higher than the L2 writing anxiety levels in each group.

As shown on Table 10, $\mathrm{C} 1$ has the highest writing tension and anxiety levels among groups because of the relatively heavy workload and the timed writing in class. The sophomores have the highest difference between the tension and the anxiety level. Besides, the sophomores have greater L2 writing tension and anxiety levels than the freshmen due to task complexity (essay writing vs. paragraph writing). Even though the sophomore-freshman tension and anxiety difference is tiny, the overall difference between tension and anxiety is much greater (.05 vs. .32). Figure 1 illustrates the relation of L2 writing tension and anxiety.

To further verify whether the difference is statistically significant, the paired-sample $t$ test was performed. Table 11 shows the L2 writing tension and anxiety difference significantly exist in C1, C2, C3 (FS or freshmen), SS (sophomores), and the overall group at the .05 level or better. If the L2 writing anxiety questions (Table 6) are seen as the pre-test and the L2 tension questions as the post-test, the L2 tension level higher than the anxiety level could be explained logically because the writing tension Table 9) is mainly induced by the actual situations and classroom activities. That is, the participants worry about the real situations and the actual classroom activities more than the vague fears coming from nowhere (Figure 1).

Table 9. L2 Writing Tension Questionnaire Results by Group

\begin{tabular}{lccccc}
\hline & C1 & C2 & SS & FS & All \\
\hline 1. I worry about making grammatical errors. & 3.24 & 3.08 & 3.17 & 2.90 & 3.06 \\
2. I worry about wrongly using words. & 3.12 & 3.15 & 3.13 & 2.95 & 3.06 \\
3. I worry about wrong style and structure. & 3.06 & 3.15 & 3.10 & 3.00 & 3.06 \\
4. I worry about insufficient time (time limit). & 3.18 & 3.15 & 3.17 & 2.95 & 3.08 \\
5. I worry about no options for the topic. & 2.65 & 3.00 & 2.80 & 2.71 & 2.76 \\
7. I worry about peer review. & 2.65 & 2.46 & 2.57 & 2.52 & 2.55 \\
8. I worry about having no idea what to write about. & 3.24 & 3.08 & 3.17 & 2.95 & 3.08 \\
9. I worry about poor grade on composition. & 3.24 & 3.00 & 3.13 & 3.10 & 3.12 \\
10. I worry about poor grades on midterm and final exam. & 3.18 & 2.92 & 3.07 & 3.05 & 3.06 \\
11. I am afraid of writing narrative essays. & 2.71 & 2.54 & 2.63 & 2.76 & 2.69 \\
12. I am afraid of writing comparative essays. & 2.82 & 2.62 & 2.73 & 2.71 & 2.73 \\
13. I am afraid of writing cause and effect essays. & 2.76 & 2.54 & 2.67 & 2.76 & 2.71 \\
14. I am afraid of writing argumentative essays. & 3.12 & 2.92 & 3.03 & 2.81 & 2.94 \\
Average & 3.00 & 2.89 & 2.95 & 2.86 & 2.92 \\
\hline Q6 was removed because of insignificant correlation within group. & & & & & \\
6. I worry about negative comments from the teacher. & 2.59 & 2.46 & 2.53 & 2.52 & 2.53
\end{tabular}

Table 10. L2 Writing Tension and Anxiety Differences by Groups

\begin{tabular}{|c|c|c|c|c|c|c|}
\hline Group & $\mathrm{C} 1$ & $\mathrm{C} 2$ & SS & FS & SS-FS & Overall \\
\hline Tension & 3.00 & 2.89 & 2.95 & 2.86 & .09 & 2.92 \\
\hline Anxiety & 2.74 & 2.49 & 2.62 & 2.58 & .04 & 2.60 \\
\hline T-A & .26 & .4 & .33 & .28 & .05 & .32 \\
\hline
\end{tabular}

T-A: Tension vs. Anxiety 


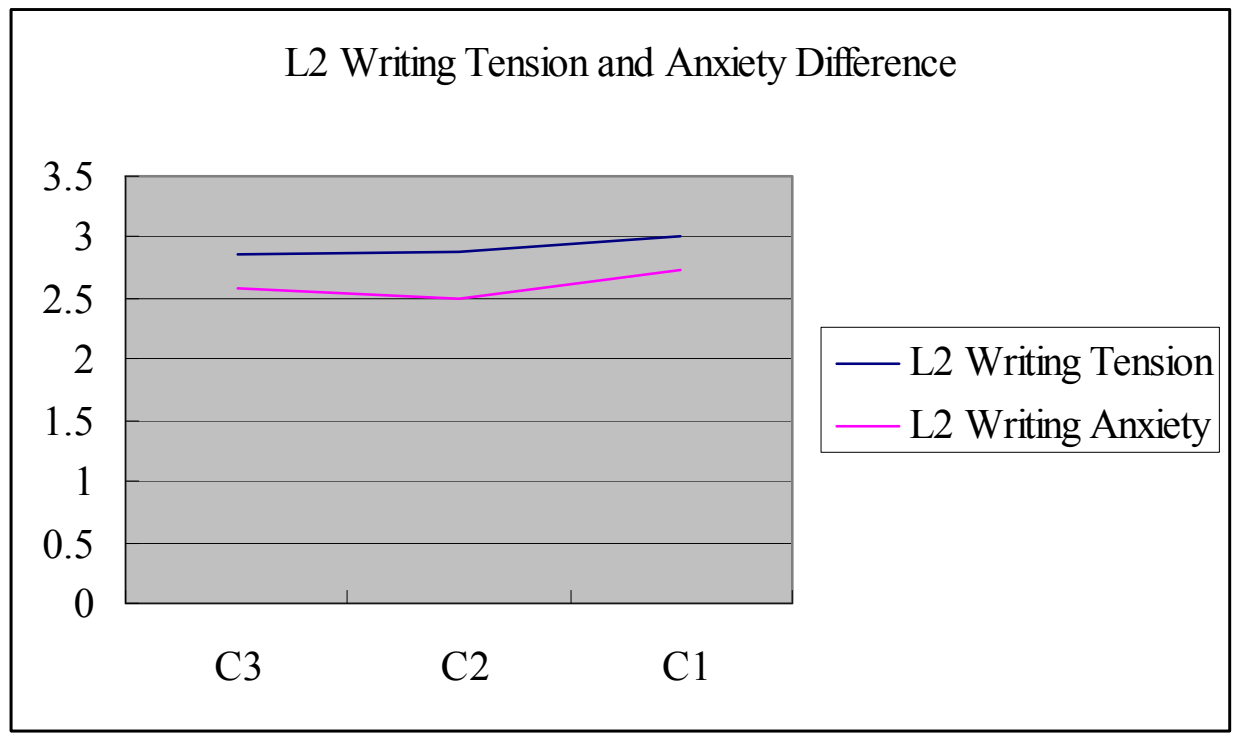

Figure 1. L2 Writing Tension and Anxiety Difference

Table 11. Paired-Sample t Test of the L2 Writing Tension and the Foreign Language Anxiety

\begin{tabular}{|c|c|c|c|c|c|c|c|c|c|}
\hline & & \multicolumn{5}{|c|}{ Paired Differences } & \multirow[b]{3}{*}{$\mathrm{t}$} & \multirow[b]{3}{*}{ df } & \multirow{3}{*}{$\begin{array}{r}\text { Sig } \\
\text { (2-tailed) }\end{array}$} \\
\hline & & \multirow[b]{2}{*}{ Mean } & \multirow[b]{2}{*}{ SD } & \multirow{2}{*}{$\begin{array}{l}\text { Std. Error } \\
\text { Mean }\end{array}$} & \multicolumn{2}{|c|}{$\begin{array}{c}95 \% \text { Confidence Interval } \\
\text { of the Difference }\end{array}$} & & & \\
\hline & & & & & Lower & Upper & & & \\
\hline T-A & Overall & .406 & .575 & .081 & .245 & .568 & 5.05 & 50 & $.000^{* *}$ \\
\hline T-A & $\mathrm{C} 1$ & .558 & .799 & .194 & .148 & .969 & 2.89 & 16 & $.011^{*}$ \\
\hline $\mathrm{T}-\mathrm{A}$ & $\mathrm{C} 2$ & .411 & .483 & .134 & .120 & .703 & 3.07 & 12 & $.010^{* *}$ \\
\hline T-A & C3 & . 287 & .377 & .082 & .115 & .458 & 3.49 & 20 & $.002 * *$ \\
\hline T-A & SS & .495 & .674 & .123 & .243 & .746 & 4.02 & 29 & $.000^{* *}$ \\
\hline
\end{tabular}

T-A: Tension vs. Anxiety

4.5 Findings of Research question 4: Does the L2 Writing Tension Questionnaire Fit in the Foreign Language Writing Anxiety Questionnaire?

To test whether the L2 Writing Tension Questionnaire (Table 9) fit in the Foreign Language Writing Anxiety Questionnaire (Table 6), the tension questions were further divided into two categories, the Real Situation (RS) and the Classroom Activity (CA), for ensuring the intra-items within category are all significantly correlated. The questions of the Real Condition category are Q1, Q2, Q3, Q4, Q8, and Q9 from Table 9, and the Classroom Activity category includes Q5, Q7, Q10, Q11, Q12, Q13, and Q14. Then, the Bivariate correlation test was carried out. Table 12 and 13 indicate they are all significantly correlated. Besides, the result on Table 14 shows both categories (RS and CA, inter-items within group) reach the significant .001 level and the $r$ values are all above .30 . The Cronbach's coefficient $\alpha$ for RS (Q1, 2, 3, 4, 8 and 9) is .90, while the Cronbach's coefficient $\alpha$ for CA (Q5, 7, 10, 11, 12, 13, and 14) is .55. The Cronbach's coefficient $\alpha$ for the total 13 questions of L2 tension questionnaire is .76. The interval consistencies are moderate that means the L2 Writing Tension Questionnaire fits in the Foreign Language Writing Anxiety Questionnaire. The New Foreign Language Writing Anxiety Questionnaire (Appendix 1) is formed. 
Table 12. Correlations of Questions in the Real Situation Category

\begin{tabular}{llrrrrrr}
\hline & & $\mathrm{Q} 1$ & $\mathrm{Q} 2$ & $\mathrm{Q} 3$ & $\mathrm{Q} 4$ & $\mathrm{Q} 8$ & $\mathrm{Q} 9$ \\
\hline Q1 & Pearson Correlation & 1 & $.737^{* *}$ & $.608^{* *}$ & $.482^{* *}$ & $.540^{* *}$ & $.507^{* *}$ \\
& Sig. (2-tailed) & & .000 & .000 & .000 & .000 & .000 \\
& $\mathrm{~N}$ & 51 & 51 & 51 & 51 & 51 & 51 \\
Q2 & Pearson Correlation & $.737^{* *}$ & 1 & $.761^{* *}$ & $.552^{* *}$ & $.477^{* *}$ & $.446^{* *}$ \\
& Sig. (2-tailed) & .000 & & .000 & .000 & .000 & .001 \\
& $\mathrm{~N}$ & 51 & 51 & 51 & 51 & 51 & 51 \\
Q3 & Pearson Correlation & $.608^{* *}$ & $.761^{* *}$ & 1 & $.663^{* *}$ & $.568^{* *}$ & $.424^{* *}$ \\
& Sig. (2-tailed) & .000 & .000 & & .000 & .000 & .002 \\
& $\mathrm{~N}$ & 51 & 51 & 51 & 51 & 51 & 51 \\
Q4 & Pearson Correlation & $.482^{* *}$ & $.552^{* *}$ & $.663^{* *}$ & 1 & $.551^{* *}$ & $.571^{* *}$ \\
& Sig. (2-tailed) & .000 & .000 & .000 & & .000 & .000 \\
& $\mathrm{~N}$ & 51 & 51 & 51 & 51 & 51 & 51 \\
Q8 & Pearson Correlation & $.540^{* *}$ & $.477^{* *}$ & $.568^{* *}$ & $.551^{* *}$ & 1 & $.518^{* *}$ \\
& Sig. (2-tailed) & .000 & .000 & .000 & .000 & .000 \\
& $\mathrm{~N}$ & 51 & 51 & 51 & 51 & 51 & 51 \\
Q9 & Pearson Correlation & $.507^{* *}$ & $.446^{* *}$ & $.424^{* *}$ & $.571^{* *}$ & $.518^{* *}$ & 1 \\
& Sig. (2-tailed) & .000 & .001 & .002 & .000 & .000 & \\
N & 51 & 51 & 51 & 51 & 51 & 51 \\
\hline
\end{tabular}

**. Correlation is significant at the 0.01 level (2-tailed).

Table 13. Correlations of Questions in the Classroom Activity Category

\begin{tabular}{llrrrrrrr}
\hline & & $\mathrm{Q} 5$ & $\mathrm{Q} 7$ & \multicolumn{1}{c}{$\mathrm{Q} 10$} & $\mathrm{Q} 11$ & $\mathrm{Q} 12$ & $\mathrm{Q} 13$ & $\mathrm{Q} 14$ \\
\hline $\mathrm{Q} 5$ & Pearson Correlation & 1 & $.318^{*}$ & $.584^{* *}$ & $.393^{* *}$ & $.417^{* *}$ & $.443^{* *}$ & $.304^{*}$ \\
& Sig. (2-tailed) & & .023 & .000 & .004 & .002 & .001 & .030 \\
& $\mathrm{~N}$ & 51 & 51 & 51 & 51 & 51 & 51 & 51 \\
Q7 & Pearson Correlation & $.318^{*}$ & 1 & $.308^{*}$ & $.396^{* *}$ & $.357^{*}$ & $.499^{* *}$ & $.337^{*}$ \\
& Sig. (2-tailed) & .023 & & .028 & .004 & .010 & .000 & .016 \\
& $\mathrm{~N}$ & 51 & 51 & 51 & 51 & 51 & 51 & 51 \\
Q10 & Pearson Correlation & $.584^{* *}$ & $.308^{*}$ & 1 & $.574^{* *}$ & $.398^{* *}$ & $.576^{* *}$ & $.491^{* *}$ \\
& Sig. (2-tailed) & .000 & .028 & & .000 & .004 & .000 & .000 \\
& $\mathrm{~N}$ & 51 & 51 & 51 & 51 & 51 & 51 & 51 \\
Q11 & Pearson Correlation & $.393^{* *}$ & $.396^{* *}$ & $.574^{* *}$ & 1 & $.399^{* *}$ & $.459^{* *}$ & $.486^{* *}$ \\
& Sig. (2-tailed) & .004 & .004 & .000 & & .004 & .001 & .000 \\
& $\mathrm{~N}$ & 51 & 51 & 51 & 51 & 51 & 51 & 51 \\
Q12 & Pearson Correlation & $.417^{* *}$ & $.357^{*}$ & $.398^{* *}$ & $.399^{* *}$ & 1 & $.792^{* *}$ & $.580^{* *}$ \\
& Sig. (2-tailed) & .002 & .010 & .004 & .004 & & .000 & .000 \\
& $\mathrm{~N}$ & 51 & 51 & 51 & 51 & 51 & 51 & 51 \\
Q13 & Pearson Correlation & $.443^{* *}$ & $.499^{* *}$ & $.576^{* *}$ & $.459^{* *}$ & $.792^{* *}$ & 1 & $.695^{* *}$ \\
& Sig. (2-tailed) & .001 & .000 & .000 & .001 & .000 & & .000 \\
& $\mathrm{~N}$ & 51 & 51 & 51 & 51 & 51 & 51 & 51 \\
Q14 & Pearson Correlation & $.304^{*}$ & $.337^{*}$ & $.491^{* *}$ & $.486^{* *}$ & $.580^{* *}$ & $.695^{* *}$ & 1 \\
& Sig. (2-tailed) & .030 & .016 & .000 & .000 & .000 & .000 & \\
& $\mathrm{~N}$ & 51 & 51 & 51 & 51 & 51 & 51 & 51 \\
\hline
\end{tabular}

*. Correlation is significant at the 0.05 level (2-tailed).

**. Correlation is significant at the 0.01 level (2-tailed). 
Table 14. Correlations by Category

\begin{tabular}{llrrrrrrr}
\hline & GW & CP & SFT & PP & LD & RS & CA \\
\hline GW & Pearson Correlation & 1 & $.893^{* *}$ & $.836^{* *}$ & $.857^{* *}$ & $.884^{* *}$ & $.511^{* *}$ & $.463^{* *}$ \\
& Sig. (2-tailed) & & .000 & .000 & .000 & .000 & .000 & .001 \\
& N & 51 & 51 & 51 & 51 & 51 & 51 & 51 \\
CP & Pearson Correlation & $.893^{* *}$ & 1 & $.871^{* *}$ & $.816^{* *}$ & $.789^{* *}$ & $.536^{* *}$ & $.529^{* *}$ \\
& Sig. (2-tailed) & .000 & & .000 & .000 & .000 & .000 & .000 \\
& N & 51 & 51 & 51 & 51 & 51 & 51 & 51 \\
SFT & Pearson Correlation & $.836^{* *}$ & $.871^{* *}$ & 1 & $.859^{* *}$ & $.848^{* *}$ & $.434^{* *}$ & $.501^{* *}$ \\
& Sig. (2-tailed) & .000 & .000 & & .000 & .000 & .001 & .000 \\
& N & 51 & 51 & 51 & 51 & 51 & 51 & 51 \\
PP & Pearson Correlation & $.857^{* *}$ & $.816^{* *}$ & $.859^{* *}$ & 1 & $.875^{* *}$ & $.380^{* *}$ & $.398^{* *}$ \\
& Sig. (2-tailed) & .000 & .000 & .000 & & .000 & .006 & .004 \\
& N & 51 & 51 & 51 & 51 & 51 & 51 & 51 \\
LD & Pearson Correlation & $.884^{* *}$ & $.789^{* *}$ & $.848^{* *}$ & $.875^{* *}$ & 1 & $.458^{* *}$ & $.386^{* *}$ \\
& Sig. (2-tailed) & .000 & .000 & .000 & .000 & & .001 & .005 \\
& N & 51 & 51 & 51 & 51 & 51 & 51 & 51 \\
RS & Pearson Correlation & $.511^{* *}$ & $.536^{* *}$ & $.434^{* *}$ & $.380^{* *}$ & $.458^{* *}$ & 1 & $.611^{* *}$ \\
& Sig. (2-tailed) & .000 & .000 & .001 & .006 & .001 & & .000 \\
& N & 51 & 51 & 51 & 51 & 51 & 51 & 51 \\
CA & Pearson Correlation & $.463^{* *}$ & $.529^{* *}$ & $.501^{* *}$ & $.398^{* *}$ & $.386^{* *}$ & $.611^{* *}$ & 1 \\
& Sig. (2-tailed) & .001 & .000 & .000 & .004 & .005 & .000 & \\
& $\mathrm{~N}$ & 51 & 51 & 51 & 51 & 51 & 51 & 51 \\
\hline
\end{tabular}

**. Correlation is significant at the 0.01 level (2-tailed).

\subsection{Findings of Research Question 5: What Are the Ways to Reduce L2 Writing Tension?}

Regarding how to reduce the participants' L2 writing tension, the students were asked to check how strongly they agreed or disagreed on the statements (Table 15) with a 4-point Likert scale. The ways to reduce L2 Writing Tension according to Table 15, are summarized in the follows:

$$
\begin{array}{ll}
\text { a. } & \mathrm{C} 1: \mathrm{Q} 10>\mathrm{Q} 3>\mathrm{Q} 1>\mathrm{Q} 2 \mathrm{Q} 8>\mathrm{Q} 9>\mathrm{Q} 7 \\
\text { b. } & \mathrm{C} 2: \mathrm{Q} 10>\mathrm{Q} 2, \mathrm{Q} 8>\mathrm{Q} 3>\mathrm{Q} 1>\mathrm{Q} 9>\mathrm{Q} 7 \\
\text { c. } & \mathrm{SS}: \mathrm{Q} 10>\mathrm{Q} 2, \mathrm{Q} 3>\mathrm{Q} 1, \mathrm{Q} 8>\mathrm{Q} 9>\mathrm{Q} 7 \\
\text { d. } & \text { FS: } \mathrm{Q} 10>\mathrm{Q} 3, \mathrm{Q} 8>\mathrm{Q} 2>\mathrm{Q} 1>\mathrm{Q} 9>\mathrm{Q} 7
\end{array}
$$

$$
\text { All: } \mathrm{Q} 10>\mathrm{Q} 3>\mathrm{Q} 2>\mathrm{Q} 8>\mathrm{Q} 1>\mathrm{Q} 9>\mathrm{Q} 7
$$

Q4, Q5, and Q6 are removed from Table 15: Ways to Reduce L2 Writing Tension due to insignificant correlation within group. If they are NOT removed, the results are as follows:
a. $\mathrm{C} 1: \mathrm{Q} 4>\mathrm{Q} 10>\mathrm{Q} 3>\mathrm{Q} 1>\mathrm{Q} 2, \mathrm{Q} 5 \cdots>\mathrm{Q} 6$
b. $\mathrm{C} 2: \mathrm{Q} 4>\mathrm{Q} 10>\mathrm{Q} 5>\mathrm{Q} 2, \mathrm{Q} 8 \cdots>\mathrm{Q} 7$
c. $\quad \mathrm{SS}: \mathrm{Q} 4>\mathrm{Q} 10>\mathrm{Q} 5>\mathrm{Q} 2, \mathrm{Q} 3>\cdots>\mathrm{Q} 7$
d. FS: Q10 $>$ Q4 $>$ Q3, Q8 $>$ Q2 $\cdots>$ Q6
e. All: Q4 $>$ Q10 $>$ Q2 $>$ Q5, Q8 $>\cdots>$ Q7

The results (Q4, Q5, and Q6 are removed) surface a pattern that the midterm and the final exam are the greatest tension source (Q10), while the peer review activity causes the least tension. In view of the tension results, L2 writing teachers may want to ask students to write compositions as the midterm and the final exam and cancel the tests, if reducing tension is the main concern. Meanwhile, because peer review activity causes the least tension, L2 writing teachers may want to exercise this teaching approach from time to time to reduce students' tension. Q4, Q5, and Q6 are removed from the questionnaire because of insignificant correlation within the group. If they are not removed, Q4 (Without time constraint, my tension in English writing can be reduced) actually has the highest tension. This is due to, for example, the $\mathrm{C} 1$ teacher told the students from the first class meeting that writing 300 words in 30 minutes is her training goal. She gave more time for the first three writing exercises, then, gradually, she requested the students timed writing in class for the last two essays. And most of the students finished their 300-word essays in 
30 minutes. In this regard, L2 writing teachers have to seek a balance between tension reducing and the training goal achieving. If Q4, Q5, and Q6 are NOT removed from the questionnaire, C1 and the freshmen (C3) considered the teacher's comments caused the least tension in English writing (Q6).

Table 15. Ways to Reduce L2 Writing Tension

\begin{tabular}{|c|c|c|c|c|c|}
\hline & $\mathrm{C} 1$ & $\mathrm{C} 2$ & SS & FS & ALL \\
\hline $\begin{array}{l}\text { 1. If grammar isn't graded, my tension in English } \\
\text { writing can be reduced. }\end{array}$ & 3.06 & 2.54 & 2.83 & 3.05 & 2.92 \\
\hline $\begin{array}{l}\text { 2. If the teacher doesn't grade on vocabulary and } \\
\text { wording, my tension in English writing can be } \\
\text { reduced. }\end{array}$ & 3.00 & 2.77 & 2.90 & 3.10 & 2.98 \\
\hline $\begin{array}{l}\text { 3. If the teacher doesn't consider style and } \\
\text { construction, my tension in English writing can } \\
\text { be reduced. }\end{array}$ & 3.12 & 2.62 & 2.90 & 3.14 & 3.00 \\
\hline $\begin{array}{l}\text { 7. Without peer review, my tension in English } \\
\text { writing can be reduced. }\end{array}$ & 2.65 & 2.23 & 2.47 & 2.76 & 2.59 \\
\hline $\begin{array}{l}\text { 8. If the teacher suggests the content for writing, my } \\
\text { tension in English writing can be reduced. }\end{array}$ & 2.88 & 2.77 & 2.83 & 3.14 & 2.96 \\
\hline $\begin{array}{l}\text { 9. If the teacher doesn't grade on the composition, } \\
\text { my tension in English writing can be reduced. }\end{array}$ & 2.76 & 2.46 & 2.63 & 2.81 & 2.71 \\
\hline $\begin{array}{l}\text { 10. If there are no midterm and final exam, my } \\
\text { tension in English writing can be reduced. }\end{array}$ & 3.35 & 3.08 & 3.23 & 3.33 & 3.27 \\
\hline Average & 2.97 & 2.64 & 2.83 & 3.05 & 2.92 \\
\hline \multicolumn{6}{|c|}{ Q4, Q5, and Q6 are removed due to insignificant correlation within group. } \\
\hline $\begin{array}{l}\text { 4. Without time constraint, my tension in English } \\
\text { writing can be reduced. }\end{array}$ & 3.47 & 3.15 & 3.33 & 3.24 & 3.29 \\
\hline $\begin{array}{l}\text { 5. If I can choose the topic to write, my tension in } \\
\text { English writing can be reduced. }\end{array}$ & 3.00 & 2.92 & 2.97 & 2.95 & 2.96 \\
\hline $\begin{array}{l}\text { 6. If the teacher doesn't give negative comments, } \\
\text { my tension in English writing can be reduced. }\end{array}$ & 2.59 & 2.62 & 2.60 & 2.71 & 2.65 \\
\hline
\end{tabular}

\section{Conclusion and Suggestion}

The major findings of the study include:

a) The female in the study have higher anxiety than the male when they practice English writing at home and feel overwhelmed by the number of rules they have to learn to write essays. In pedagogy, the grammatical tools including textbooks, dictionary, network tools, and/or handouts could be made available to female students when they practice English writing at home. Further research might want to look into this phenomenon.

b) By category, every group identifies the language difficulties (LD) inducing the highest anxiety on the foreign language anxiety questionnaire (Table 6), whereas stress from teacher (SFT) evokes the least anxiety. Among groups against questions, a pattern seems to emerge that the sophomores consider the fear of writing in class (Q1) has the highest anxiety, whereas the freshmen most worry about the consequence of failing the writing class (Q2). In the overall group, Q31: writing without any concept of structure and style in mind brings about the highest anxiety. By and large, Q8, Q18 and Q23 evoke the least anxiety (table 6).

c) Regarding the L2 writing tension results, poor grade on composition (Q9) is the most worried item in the overall group, followed by the worries of writing with limited time (Q4) and having no idea what to write about (Q8). Throughout the groups, the participants least worried about peer review (Q7). Peer review activity seems to be an effective teaching strategy for reducing writing tension. L2 writing teachers may want to try it sometime in class, if reducing students' tension is concerned. Future research might want to look closely into the peer review method regarding why it is the lowest tension evoker because some studies report that interpersonal threat or peer pressure is one of the main causes of anxiety.

d) Notably, L2 writing tension is significantly higher than the foreign language writing anxiety in each group that indicates the participants worry about actual situations and authentic classroom activities more than the anxiety 
evoked from vague fears.

e) The L2 writing tension questionnaire significantly correlated to the foreign language writing anxiety questionnaire. Therefore, they are combined together to form the New Foreign Language Writing Anxiety Questionnaire (NFLWAQ). Future users of the NFLWAQ may choose a few parts of it or use it as a whole depending on their purpose of study. Future research should be done to a larger scale of participants. The present study is just a simple version showing how to construct one's questionnaire. If an anxiety/tension "scale" is attempted, then, the test and re-test of the reliability and the correlation with the existing Scales are bound to do just as Cheng did (2004b). Besides, more question items need to be added to the categories of Peer Pressure, Stress from Teacher, and Language Difficulties.

f) In seeking ways to reduce L2 writing tension, statistics surface a pattern (Summary of Table 15) that the midterm and the final exam are the greatest tension source of L2 writing, while the peer review activity evokes the lowest tension (If not removed, the timed writing caused the highest tension). In addition to the peer review approach that can be used as a teaching strategy for alleviating tension, there are ways to reduce L2 writers' tension, for instance, find some other ways to replace midterm and final exam; don't consider style and construction sometimes when grade on students' composition; don't grade on vocabulary and wording from time to time; and suggest content for writing, etc. However, L2 and/or FL writing teachers have to find the best balance between the training objectives and the tension reducing. Even though, theoretically, Spielmann \& Radnofsky (2001) claimed there was no need to reduce or suppress the affective dysphoria (namely stress, tension, or anxiety), educators all know that when the pressure arises to some extent, the explosion forces could jeopardize the instructor's job, the program's endurance, the university reputation as well. After all, the Middlebury College Language Schools is an extreme case that the participants in there have much stronger motivation for learning second/foreign language in a short time period and in an isolated location. Most second/foreign language programs in the world bear no intention to risk the setbacks the affective dysphoria pressure brings about.

\section{References}

Alrabai, Fakieh. (2014). The influence of teachers' anxiety-reducing strategies on learners' foreign language anxiety. Innovation in Language Learning and Teaching, 9(2), 163-190. http://dx.doi.org/10.1080/17501229.2014.890203

Aydin, Selami (2007). How Can Teachers Reduce Test Anxiety of L2 Learners? Humanising Language Teaching, 9(4), July 2007. Retrieved on July 22, 2017 from http://hltmag.co.uk/jul07/sart05.htm

Bailey, P., Daley, C., \& Onwuegbuzie, A. J. (1999). Foreign language anxiety and learning styles. Foreign Language Annals, 32, 62-76. https://doi.org/10.1111/j.1944-9720.1999.tb02376.x

Brown, D. (1994). Principles of language teaching and learning. New Jersey: Prentice Hall.

Cheng, Y. S. (2002). Factors associated with foreign language writing anxiety. Foreign Language Annals, 35(6), 647-656. https://doi.org/10.1111/j.1944-9720.2002.tb01903.x

Cheng, Y. S. (2004a). EFL students' writing anxiety: Sources and implications. English Teaching \& Learning, 29(2), 41-62.

Cheng, Y. S. (2004b). A measure of second language writing anxiety: Scale development and preliminary validation. Journal of Second Language Writing, 13(4), 313-335. http://dx.doi.org/10.1016/j.jslw.2004.07.001.

Choi, Sujeong (2013). Language anxiety in second language writing: Is it really a stumbling block? Second Language Studies, 31(2), 1-42.

Daly, J. A., \& Miller, M. D. (1975a). The empirical development of an instrument to measure writing apprehension. Research in the Teaching of English, 9, 242-249.

Daly, J. A., \& Miller, M. D. (1975b). Further studies on writing apprehension: SAT scores, success expectations, willingness to take advanced courses and sex difference. Research in the Teaching of English, 9, 250-256.

Donley, Philip. (1997). Ten ways to cope with foreign language anxiety. Mosaic: A Journal for Language Teachers, 4(3), 17.

Ellis, R. (1994). The Study of Second Language Acquisition. Oxford: Oxford University Press.

Gardner, R.C., \& MacIntyre, P.D. (1993). On the measurement of affective variables in second language learning. Language Learning, 43, 157-194. https://doi.org/10.1111/j.1467-1770.1992.tb00714.x 
Horwitz, E. K., \& Young, D. J. (1991). Language Anxiety: From Theory and Research to Classroom Implications. Englewood Cliffs, NJ: Prentice Hall.

Horwitz, E. K., Horwitz, M., \& Cope, J. (1986). Foreign language classroom anxiety. The Modern Language Journal, 70, 125-132. https://doi.org/10.1111/j.1540-4781.1986.tb05256.x

Jebreil, Naghmeh, Azizifar, Akbar \& Gowhary, Habib. (2015). Investigating the Effect of Anxiety of Male and Female Iranian EFL Learners on their Writing Performance. Procedia - Social and Behavioral Sciences, 185, 190-196. https://doi.org/10.1016/j.sbspro.2015.03.360

Kırmızı, Özkan \& Kırmızı, Gülin Dağdeviren. (2015). An investigation of L2 learners' writing self-efficacy, writing anxiety and its causes at higher education in Turkey. International Journal of Higher Education, 4(2), 57-66. https://doi.org/10.5430/ijhe.v4n2p57

Lee, Sy-ying. (2005). Facilitating and inhibiting factors in English as a foreign language writing performance: A model testing with structural equation modeling. Language Learning, 55(2), 335-374. https://doi.org/10.1111/j.0023-8333.2005.00306.x

Leki, I. (1999). Techniques for reducing second language writing anxiety. In D. J. Young (Ed.), Affect in Foreign language and second language learning: A practical guide to creating a low-anxiety classroom atmosphere, 64-88. Boston: McGraw-Hill.

Lightbrown, P. M., \& Spada, N. (2006). How Languages are Learned ( $3^{\text {rd }}$ ed.). New York: Oxford University Press.

MacIntyre, P. D., \& Gardner, R. C. (1989). Anxiety and second-language learning: Toward a theoretical clarification. Language Learning, 39(2), 251-275. http://dx.doi.org/10.1111/j.1467-1770.1989.tb00423.x

Nosratinia, Mania \& Abdi, Farahnaz. (2017). The Comparative Effect of Portfolio and Summative Assessments on EFL Learners' Writing Ability, Anxiety, and Autonomy. Journal of Language Teaching and Research, 8(4) 823-834. https://doi.org/10.17507/jltr.0804.24

Piniel, K. (2006). Foreign language classroom anxiety: A classroom perspective. In M. Nikolov \& J. Horváth (Eds.), UPRT 2006: Empirical studies in English applied Linguistics.

Qashoaa, Sulaiman Hasan Hussein. (2014). English Writing Anxiety: Alleviating Strategies. Procedia - Social and Behavioral Sciences, 136, 59-65. https://doi.org/10.1016/j.sbspro.2014.05.288

Rezaei, Maliheh \& Jafari, Mohammad. (2014). Investigating the Levels, Types, and Causes of Writing Anxiety among Iranian EFL Students: A Mixed Method Design. Procedia - Social and Behavioral Sciences, 98, 1545-1554. https://doi.org/10.1016/j.sbspro.2014.03.577

Rose, M. (1984). Writer's block: The cognitive dimension. Carbondale: Southern Illinois University Press.

Scovel, T. (1978). The effect of affect on foreign language learning: A review of the anxiety research. Language Learning, 28, 129-142. https://doi.org/10.1111/j.1467-1770.1978.tb00309.x

Shehadeh, A. (2011). Effects and student perceptions of collaborative writing in L2. Journal of Second Language Writing, 20, 286-305. https://doi.org/10.1016/j.jslw.2011.05.010

Sparks, R. L., \& Ganschow, L. (1991). Foreign language learning differences: Affective or native language aptitude differences? The Modern Language Journal, 75(1), 3-16. http://dx.doi.org/10.2307/329830

Sparks, R. L., \& Ganschow, L. (1993a). The impact of native language learning problems on foreign language learning: Case study illustrations of the linguistic coding deficit hypothesis. The Modern Language Journal, 77, 58-74. http://dx.doi.org/10.2307/329559

Sparks, R. L., \& Ganschow, L. (1993b). Searching for the cognitive locus of foreign language learning difficulties: Linking first and second language learning. The Modern Language Journal, 77, 289-302. http://dx.doi.org/10.2307/329098

Sparks, R. L., \& Ganschow, L. (2007). Is the foreign language classroom anxiety scale measuring anxiety or $\begin{array}{lllll}\text { language skills? } & \text { Foreign }\end{array}$ http://dx.doi.org/10.1111/j.1944-9720.2007.tb03201.x

Sparks, R. L., Patton, J., \& Ganschow, L. (2012). Profiles of more and less successful L2 learners: A cluster analysis study. Learning and Individual Differences, 22(4), 463-472. https://doi.org/10.1016/j.lindif.2012.03.009

Spielmann, G., \& Radnofsky, M. L. (2001). Learning language under tension: New directions from a qualitative 
study. Modern Language Journal, 85(2), 259-278. https://doi.org/10.1111/0026-7902.00108

Trang, TRAN Thi Thu. (2012). A Review of Horwitz, Horwitz and Cope's Theory of Foreign Language Anxiety and the Challenges to the Theory. English Language Teaching, 5(1), 69-75.

Tsai, Min-hsiu. (2002). A study of university students' anxiety differences between traditional and online writing classes. Focus on Colleges, Universities, and Schools, 6(1), 1-20.

Young, D. (1991). Creating a Low Anxiety Classroom Environment: What does language anxiety research suggest? The Modern Language Journal, 75(4), 426-439. https://doi.org/10.1111/j.1540-4781.1991.tb05378.x

\section{Appendix 1 \\ New Foreign Language Writing Anxiety Questionnaire}

This questionnaire is to explore the anxiety levels of writing. Please circle the number that best describes your feeling from the following options: (4) strongly agree, (3) agree, (2) disagree, and (1) strongly disagree.

a. Gender:1.ロ male 2. $\quad$ female

b. Family income:
1. $\square$ under 300,000
2. $\square 300,001 \sim 500,000$
3. $\square 500,001 \sim 700,000$
4. $\square 700,001 \sim 900,000$
5. $\square 900,001 \sim 1,100,000$
6. $\square 1,100,001 \sim 1,500,000$
7. $\square$ above $1,500,000$
8. others

c. Compared with my peers, my English proficiency is
1. $\square$ very bad
2. $\square$ not good
3. $\square \operatorname{good}$
4. $\square$ very good
1. $\square$ No
2. $\square$ Yes

d. I have taken English proficiency test.

e. The biggest problem of my writing is on
1. $\square$ spelling
2. $\square$ grammar
3. $\square$ tenses
4. $\square$ structure and style
5. $\square$ all of the above

\section{General Worries (GW)}

1. I never feel quite sure of myself when I am writing in class.

2. I worry about the consequences of failing this writing class.

4. In language classes, I can get so nervous I forget things I know.

6 . I would be nervous writing to native speakers.

7. The more I study for a language test, the more confused I get.

8. I feel not confident when I practice English writing at home.

Please circle the number.
$\begin{array}{llllll}4 & 3 & 2 & 1 & \\ 4 & 3 & 2 & 1 & \\ 4 & 3 & 2 & 1 & \\ 4 & 3 & 2 & 1 & \\ & 4 & 3 & 2 & 1 \\ 4 & 3 & 2 & 1 & \end{array}$

\section{Class Performance $(\mathrm{CP})$}

9. I am usually at unease during tests in my writing class.

10. I worry about making mistakes in the writing class.

11. It would bother me very much to take more writing classes.

12. I get nervous when the writing teacher asks me to write what

I haven't prepared in advance.

13. I feel pressure to prepare very well for the writing class.

14. Even if I am well prepared for the writing class, I feel anxious about it.

15. I often feel like not going to my writing class.

16. I can feel my heart pounding when I'm going to be called on to make sentences in the writing class.

17. The writing class moves so quickly I worry about getting left behind. 4

18. I feel more tense and nervous in my writing class than in my other classes. 4

$\begin{array}{lllll}4 & 3 & 2 & 1 & \\ 4 & 3 & 2 & 1 & \\ & 4 & 3 & 2 & 1 \\ & & & & \\ 4 & 3 & 2 & 1 & \\ & 4 & 3 & 2 & 1 \\ & 4 & 3 & 2 & 1 \\ 4 & 3 & 2 & 1 & \\ & & & & \\ 4 & 3 & 2 & 1 & \\ 4 & 3 & 2 & 1 & \\ 4 & 3 & 2 & 1 & \\ & 4 & 3 & 2 & 1\end{array}$

19 . When I'm on my way to the writing class, I feel very uneasy and unsure.

\section{Stress from Teacher (SFT)}

20. I get nervous when I don't understand every word the writing teacher says. 4

21. I tremble when I know that I'm going to be called on in writing class. 4

22. I get upset when I don't understand what the writing teacher is correcting.

23. I am afraid that my writing teacher is ready to correct every mistake I make. 
Peer Pressure (PP)

24. I am afraid that the other students will laugh at my writing.

25 . I keep thinking that the other students are better at languages than I am.

26. I always feel that the other students write better than I do.

$\begin{array}{llll}4 & 3 & 2 & 1\end{array}$

$\begin{array}{lllll} & 4 & 3 & 2 & 1 \\ 4 & 3 & 2 & 1 & \\ & 4 & 3 & 2 & 1\end{array}$

\section{Language Difficulties (LD)}

28. I start to panic when I misspell in writing.

$\begin{array}{llll}4 & 3 & 2 & 1\end{array}$

29. I feel overwhelmed by the number of rules I have to learn to write essays. $\quad \begin{array}{lll}4 & 3\end{array}$

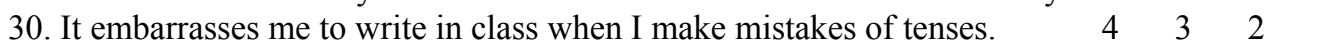

31. I get nervous and confused when I write without any concept of structure and style in mind .

\section{Real Situations (RS)}

1. Writing in English, I worry about making grammatical errors.

2. Writing in English, I worry about wrong vocabulary and wording.

3. Writing in English, I worry about structure and style.

4. Writing in English, I worry about insufficient time (time limit).

8. Writing in English, I worry about having no idea.

9. Writing in English, I worry about poor score on composition.

$\begin{array}{rrrrr} & 4 & 3 & 2 & 1 \\ & 4 & 3 & 2 & 1 \\ 4 & 3 & 2 & 1 & \\ & 4 & 3 & 2 & 1 \\ & 4 & 2 & 1 & \\ & 3 & 3 & 2 & 1\end{array}$

(The item numbers are corresponding to Table 9: the L2 Writing Tension Questionnaire.)

\section{Classroom Activity (CA)}

5. Writing in English, I worry about no options for writing topic.

7. Writing in English, I worry about peer review.

10. Writing in English, I worry about poor scores on midterm and final exam.

11. Writing in English, I worry about writing narrative essays.

12. Writing in English, I worry about writing comparative essays.

13. Writing in English, I worry about writing cause \& effect essays.

14. Writing in English, I worry about writing argumentative essays.

$\begin{array}{lllll} & 4 & 3 & 2 & 1 \\ 4 & 3 & 2 & 1 & \\ & 4 & 3 & 2 & 1 \\ 4 & 3 & 2 & 1 & \\ & 4 & 3 & 2 & 1 \\ 4 & 3 & 2 & 1 & \\ 4 & 3 & 2 & 1 & \end{array}$

(The item numbers are corresponding to Table 9: the L2 Writing Tension Questionnaire.) 